\begin{tabular}{|c|c|c|c|c|c|c|}
\hline \multirow{4}{*}{ Impact Factor: } & ISRA (India) & $=3.117$ & SIS (USA) & $=0.912$ & ICV (Poland) & $=6.630$ \\
\hline & ISI (Dubai, UAI & $=0.829$ & РИНЦ (Russia) & $=0.156$ & PIF (India) & $=1.940$ \\
\hline & GIF (Australia) & $=0.564$ & ESJI (KZ) & $=8.716$ & IBI (India) & $=4.260$ \\
\hline & JIF & $=1.500$ & SJIF (Morocco) & $=5.667$ & OAJI (USA) & $=0.350$ \\
\hline
\end{tabular}

\section{SOI: $1.1 /$ TAS DOI: $10.15863 /$ TAS International Scientific Journal Theoretical \& Applied Science}

\author{
p-ISSN: 2308-4944 (print) e-ISSN: 2409-0085 (online) \\ Year: 2019 \\ Issue: 05 \\ Volume: 73
}

Published: $21.05 .2019 \quad \underline{\text { http://T-Science.org }}$
QR - Issue

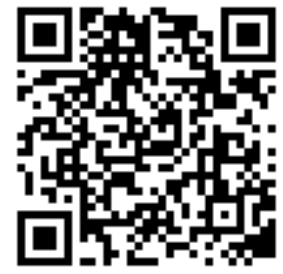

QR - Article

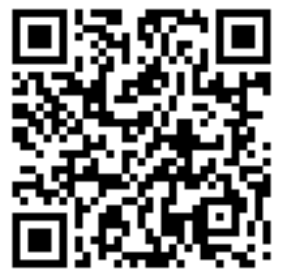

Jakhongir Tokhirov

Researcher of

the International Islamic Academy of Uzbekistan

\title{
ISLAMIC SCIENTIFIC WORKS OF ALI QUSHCHI
}

Abstract: The article tells about the life and work of Ali Qushchi (Kushchi, Kushji), who was one of the most famous and distinguished medieval scholars in Central Asia, and his contribution to science. The article also analyzes the work of Ali Qushchi in the field of Islamic sciences, in particular, the work on "kalam" (Islamic theology). The article gives a general idea that Ali Qushchi is not only an outstanding scholar in the field of secular science, but also possessed sufficient knowledge of Islamic sciences.

Key words: Islamic theology, kalam, Nasir al-din al-Ṭ̄isī, Ali Qushchi, Tajrīd al-akaid.

Language: English

Citation: Tokhirov, J. (2019). Islamic scientific works of Ali Qushchi. ISJ Theoretical \& Applied Science, 05 (73), 132-134.
Soi: http://s-0-i.org/1.1/TAS-05-73-23
Doi: crossef https://dx.doi.org/10.15863/TAS.2019.05.73.23

\section{Introduction}

Ali Qushchi's (1403-1474) full name is Alouddin Ali ibn Muhammad Qushchi Samarkandi Hanafi Ash'ari-Maturidi. His science of field are astronomy, mathematics, kalam (Islamic theology), fiqh (Islamic low), Quran Interpretation (Tafseer) [1: 227].

He was not only a well-known mathematician and astronomer in the East and West, but was an encyclopedic scientist, who theoretically and practically effectively worked in the field of research and education. He not only perfectly mastered Arabic and Persian, but also practiced them in all scientific fields of his time.

He buried in the famous cemetery Abu Ayyub Ansari at Istanbul. The marble stone in entrance engraved with the words "Ali Qushchi is a man of knowledge".

\section{Materials and Methods}

Ali Qushchi wrote works on the exact, natural and humanity sciences, as well as on such Islamic sciences as tafseer, fiqh and aqida (kalam).

His nearly 30 works can be classified into three groups: exact sciences; logic and linguistics; following works of Islamic sciences:

1. Ali Qushchi's margins on Taftazoni's (13221392) commentary of Mahmud Zamakhshari's (10751144) "Tafseer al-Kashshof".
2. Ali Qushchi's margins on the "Sharh alMatole" of Qutbuddin Tahtoni (d.1365).

3. Ali Qushchi's commentary on "Mukhtasar alWiqaya" of Ubaydullah ibn Mas'ud (d.1238) [2:99]

4. Ali Qushchi's margins on "Mukhtasar almuntaha fi usul al-fiqh" of Ibn al-Khojib. [3:1]

5. "Ar-Risala al-Muta'alliqa bi-kalima attawheed". His manuscripts are kept in libraries of Berlin and Rome.

6. Ali Qushchi's commentary on "al-Fiqh alAkbar" of Imam A'zam Abu Khanifah. Only one copy of the manuscript is stored in the Kazan University Library [4:1]

7. "Tafseer az-Zakhravayn" is a interpretation of Suras al-Baqara and Ali-Imran [5: 448].

8. "Khoshiya alat-Talvih" - Ali Qushchi's margins of Taftazani's commentary "Talwih" on Ubaydullah ibn Mas'ud's "Tavzih sharh li-Tanqih" about Usul Al-Fiqh [6: 194]. The copy is stored in the Library of Sulemaniya. Jarulloh Afandi № 1438/2.

9. Ali Qushchi's commentary on Nasiruddin Tusi's (1201-1274) "Tajreed al-Aqoid".

Usually, when studying the scientific heritage of a scientist, it is observed that he has worked a particular direction of maz'hab or science. The unique of Ali Qushchi is that he wrote commentaries and refutations on the works of the great scholars of the various maz'habs as Hanafi jurisprudence, Ash'ariMoturidi, Mu'tazila and Shia aqeedah. The fact that fundamental scientifically-practical research on 


\begin{tabular}{|c|c|c|c|c|c|c|}
\hline \multirow{4}{*}{ Impact Factor: } & ISRA (India) & $=3.117$ & SIS (USA) & $=0.912$ & ICV (Poland) & $=6.630$ \\
\hline & ISI (Dubai, UAI & $=0.829$ & РИНЦ (Russia & $=0.156$ & PIF (India) & $=1.940$ \\
\hline & GIF (Australia) & $=0.564$ & ESJI (KZ) & $=8.716$ & IBI (India) & $=4.260$ \\
\hline & JIF & $=1.500$ & SJIF (Morocco & $=5.667$ & OAJI (USA) & $=0.350$ \\
\hline
\end{tabular}

Islamic sciences such as aqida, tafseer and fiqh, as well as logic, exact and natural sciences, is a sign of how comprehensible he was.

Some sources provide information that the above-mentioned works ware written by Ali Qushchi. However, many copies still have not been found. It is known that the two books at the end of this list were partly studied abroad (Turkey, Egypt and Iran).

The most famous of them is "Sharh Tajreed alAqaid", it's the Ali Qushchi's commentary on Nasiruddin Tusi's Tajreed al-Aqaid. Tusi is from Maveraunnakhr, a native of Marv. He wrote in his introduction: "The people asked me to sort out the Issues of Kalam, I replied, and called it Tajreed alAqaid." [7: 3957]

In the sources it's named in different, such as AtTajreed, Tajreed al-Aqaid, Tajreed al-E'tiqad, Tajreed al-Kalam. Ali Qushhi's commentary also named in different, such as at-Tajreed, at-Tajreed al-Jadid, ashSharh al-Jadid lit-Tajreed [8:1].

Although in different names, the essence is the same meaning, the issues of belief in Islamic teachings. This branch of Islamic sciences, which was originally known as "Fiqh al-akbar," later used in the Muslim East such as "Kalam", "Usuli Din", "Tawheed", "Aqaid". In Western Orientalism, "Islamic Philosophy" and "Islamic Theology" names are mentioned.

Nasiruddin Tusi's Tajreed al-Aqaid was published in Egypt in 1996, which informed that Ali Qushchi and Shamsuddin Muhammad Isfakhani (1275-1348) commented on it [9:194].

Many commentaries and margins have also been written on it. Ali Qushchi highly appreciated in his introduction that Shamsuddin Muhammad Isfakhaniy and Sayyid Sharif Jurjani (1340-1413) wrote well commentaries on this work. Ali Qushchi's commentary was the most famous of them, and in the later periods, more than 20 margins on it was written.

The name of Isfakhani's commentary is "Tashyeed al-qawaid fi sharhi Tajreed al-Aqaid", which is briefly called "at-Tajreed al-qadim" (ancient interpretation), and Ali Qushi's commentary is called "At-Tajreed al-jadid" (new interpretation) [10: 249].

The work is presented in many sources and in the "Mu'jam al-Matbuat" (11: 170), which contains short information about the names of the books published in the east and western countries by the end of 1919, and the names of their translations.

Including, "Ali Qushchi is one of the Ahli Sunna's Ash'ari imam, has book named "SharhiTajreed" [12: 1];

"Sharh At-Tajreed belongs to mavla Ali Qushchi" [13: 1];

"Sharh Tajreed al-kalam" There is a lithoprint (stone print) for 1884, with a total of 429 pages [14: $1]$.
In the lithoprint copy of 1858 the work's full name is called "Sharh Tajreed al-kalam fi tahrir alaqaid al-Islam" [15: 1].

Orientalist Ashraf Akhmedov says that, "Ali Qushchi wrote it in 1417 in the city of Cermon in Iran and was the first work. His manuscripts are kept in the British Museum, the Imam Reza Library in Mashhad, the Ayo Sufian Library in Istanbul, the Tehran University Library, the Abu Raykhon Beruni Institute of Oriental Studies at the Academy of Sciences of the Republic of Uzbekistan (14 copies) and in the public library in Saint Petersburg." [4: 1]

Ali Qushchi later presented this work to Abu Said Khan [16: 1].

There are also several manuscripts in the Turkish libraries of Suleymaniye, Nuriusmania, Kayseri Rashid Efendi and Istanbul [17: 410].

Many margins was written on Ali Qushchi's commentary. In particular, Ahmad Ardabili's "AlKhashiya ala Ilahiyat al-Sharh al-Jadeed litTajreed". Ahmad A'bidiy has studied its part of theology.

Another research, "Min Al-Turath al-Islamiy / Sharh Ali Qushchi ala Tajreed al-Aqaid lit-Tusi / Mabhas al-ilahiyat" was made by Sabir Abduh Abu Zayd the doctor of the University of Janub al-Vadi in Alexandria, Egypt [18: 90].

The unknown author copy of the book, "Mabakhis al-Javahir val-a'raz min kitab sharh atTajreed", dated 1654, which is stored in the Library of Congress Library Mansuriy, shows that some parts of the work have been published in a separate book [19: 398].

Also, the first part of Ali Qushchi's commentary - "The First Purpose is General Affairs" was published in 2014 by Zariy Ridai in the Iranian city of Kum.

Jalaliddin Davvani (1427-1502) wrote persian "Khashiyati Sharhi Qushchi". With name "Sharhi Qushchi", he classified in the three books: "The essence of the commentary is Tajreed Qushchi", "The essence of the jadid bar commentary Tajreed Qushchi", "The essence of the ancient bar comment Tajreed Qushchi". This third paragraph is a commentary on the commentary of "Tajreed" in the book "Ajaddu seasons". It is written in Mu'jam alBughdon, "The margins on the Qushchi's commentary" published in Istanbul. However, it is not clear which published one of the three above mentioned is the margin [20:1].

In the manuscript margin of Jalal al-Din alDavvaniy on Ali Qushchi's commentary which $1335^{\text {th }}$ hijri edition, the theological issues was described on six targets. [21: 228]

Ali Qushchi (1401-1474) lived 200 years later then Nasiruddin Tusi (1201-1274). His reference to his work is not accidental. Both Tusi and Ali Qushchi have written astronomical works along with Kalam and philosophy. Thus, there is a common in these two scholarly views. 


\begin{tabular}{|c|c|c|c|c|c|c|}
\hline \multirow{4}{*}{ Impact Factor: } & ISRA (India) & $=3.117$ & SIS (USA) & $=0.912$ & ICV (Poland) & $=6.630$ \\
\hline & ISI (Dubai, UAI & $=0.829$ & РИНЦ (Russia & $=0.156$ & PIF (India) & $=1.940$ \\
\hline & GIF (Australia) & $=0.564$ & ESJI (KZ) & $=8.716$ & IBI (India) & $=4.260$ \\
\hline & JIF & $=1.500$ & SJIF (Morocco & $=5.667$ & OAJI (USA) & $=0.350$ \\
\hline
\end{tabular}

It is a philosophical and metaphysical approach, which is slightly different from classical interpretations of theological issues. In the commentary of the work, it is possible to reconcile such expressions as "this is a Shia's view, and that is Ahl al-Sunna's, or the Ash'ari's view", and some statements of the Zoroasterizm. It is difficult to feel the effects of the periodic environment in writing the review. Because, in the content of the work, it is difficult to find such information that point to this.

\section{Conclusion}

Summing up, many commentaries and margins have been written on Ali Qushchi's this work in various periods of times, and have been copied at different times, this shows that, always appealed to it and how important it is to have. Several scientists of his time wrote a commentaries on this work, it shows that, how much they appreciate this work. This work is still being taught as a textbook in Iranian madrasas.

\section{References:}

1. (n.d.). Retrieved 2019, from http://almerja.com/reading.php?idm $=15250$ الأعلام : 9/5 ؛ معجم المؤلفين : 227/7 ؛ ريحانة الأدب : 495/4.

2. Taşköprüzoda, M. (1561). Shaqoiq UnNu'moniya / Dor al-kitab al-Arabi / Beirut /1975. See also: Abdulhay Laknavi (1847-1886) / Umdat ur-rioya (The margins of al-Wiqaya's commentary). Hamidullah Beruniy https://ahlisunna.uz/moturidiylar-haqidabashorat/

3. Riza, U. (1993). "Mu'jam al-muallifeen". Muassasa ar-Risala.

4. Ahmedov, A. (n.d.). Retrieved 2019, from http://www.e-tarix.uz/shaxslar/506-cola.html

5. Khaji, K. (1941). Kashf az-zunun, Beirut, Volume 1, 14: 264. See also: Ilay Next / Journal of the Center for Ottoman Studies, Ankara University (OTAM), vol. 20/2006, p.183; Cengiz Aydin / TDV Islamic Encyclopedia, 1989, Volume 2, Volume 410.

6. Özer, H., \& Ali Kuş̧̧u ve (2009). "Haşiye 'ale'ttelvih" adli eseri / İslam hukuku araştirmalari dergisi, Sayl:13 | Nisan 2009, p.361.

7. (n.d.). "Dar al-Kutub al-Misriya". 1311 h.y. Published in India in Stonehenge № 3957. King Saud University.

8. (1993). "Mir'at al-Kutub", Mirzo Ali Hoiriy Muhammad Ali, Maktabat Ayatullah alMar'ashi al- 'amma, Vol. 1.

9. (1996). Dar al-ma'rifat al-jomiya, Egypt (Cairo, Alexandria). p. 194.

10. (1900). Al-fawâid al-bahiya fi tarâjim alHanafiya, Muhammad Abdulhay, Dar AlMa'rifa, p.249.
11. (1928). "Mujam al-Matbuat al-Arabiya valmu'raba", Yusuf Ilyan, matbaa Sarkis, 1928. Volume 2, p.170.

12. (2006). "Mavsu'a al-imam as-Sayyid Abdulhusayn Sharafuddin", Dar al-Muarrixeen al-Arabi, Volume 1.

13. (1981) "Riyâd al'ulamâ wa-ḥiyādat al-fuḍalā", Volume 1, Abd Allāh ibn 'Āsā Afandī, Aḥmad Hūsīnī, Maktabat Āyat Allaah al-Mar'āshī al'àmma.

14. (n.d.). Princeton University Arabic collection: Phase II.

15. (n.d.). Early Arabic Printed Books from the British Library.

16. (n.d.). Retrieved 2019, from http://www.biografya.com/biyografi/3678

17. (n.d.). Sulaymoniya: No. I, 821, 822; II, 151. Nuriusmonia: № 2104/2. Kayseri Rashid Efendi, No.484). Also published in Tabriz (h. $1301 /$ m.1880). (Istanbul: No. 74152, 82016). Cengiz (1989). Aydin / TDV Islamic Encyclopedia, Volume 2, Volume 410.

18. (2002). Dar al-vafa li dunya al-Tabâa wa'lnashr. p.90.

19. (1654). Commentary on the section on substance and accident. p.398.

20. Nurmuhamedov, D. (2014). Retrieved 2019, from http://davron28.fikr.uz/ 21.06.2014 http://fikr.uz/blog/toshkent_islom_universiteti/2 $\underline{0848 . h t m l}$

21. (1966). Harvard University Library / OL 22800.10.5F. 